\title{
The significance of timing and duration of social assistance receipt during childhood on early adult outcomes
}

\author{
Tiina Ristikari \\ tiina.ristikari@thl.fi \\ Marko Merikukka \\ Mia Hakovirta
}

(Received July 2017

\author{
National Institute of Health and Welfare, Finland \\ National Institute of Health and Welfare, Finland \\ University of Turku, Finland
}

\section{Abstract}

The experience of economic disadvantage during childhood is a major predictor of a variety of negative outcomes during early adulthood. This study provides evidence on the significance of timing of social assistance receipt during childhood on children's later adjustment problems. The study uses data from the 1987 Finnish Birth Cohort (FBC), which covered all children born in Finland in 1987 ( $N=59476)$ and followed them until the age of 25 . The data were gathered from Finnish registers that cover health and sociodemographic data for cohort members and their parents. Altogether 11,062 female (38.1\%) and 11,537 male $(37.9 \%)$ cohort members had parents who had received social assistance. Social assistance receipt during childhood increased the risk for all measured adjustment problems: early school leaving (OR 2.37), conviction (OR 1.87), teenage pregnancy (OR 1.89) and mental disorders (OR 1.68) even when adjusting for several social background variables. Economic disadvantage during early childhood ( $0-2$ years) was found to associate with highest risk; all measured adjustment problems compared to exposure to poverty later in childhood. The study concludes that early childhood is a period in which children acquire cognitive and social competencies that form the basis for future wellbeing. Our analysis, based on a total nation-wide birth cohort, indicates that economic disadvantage in early childhood poses the most significant risk for later adjustment problems.

\section{Keywords}

Social assistance; early adult outcome; birth cohort; registers study

\section{Introduction}

The negative impact of childhood economic disadvantage on children's later wellbeing has been documented extensively over past decades (e.g., Hansen, 2008; Holzer, Schanzenbach, Duncan, \& Ludwig, 2007; Ilmakunnas, 2018; Mayer, 1997; McLoyd, 1998; Saraceno, 2002). When comparing children from more affluent families to children living in low-income families, earlier studies have found that children growing up in poverty are more likely, for example, to have health, behavioural, and emotional problems; to drop out of school; to have low academic achievement; and a risk of an intergenerational cycle of welfare receipt (e.g. Duncan \& Brooks-Gunn, 1999; Duncan, Ziol-Guest, \& Kalil, 2010; Kauppinen et al., 2014; Nielsen, Juon, \& Ensminger, 2004). Parental income has been shown to be a more significant determinant of children's wellbeing and achievement than parental mental or physical health, maternal schooling, and family structure, for example (Duncan \& BrooksGunn, 2000). The linkages between low income and negative outcomes are particularly strong for children who are trapped in poverty for a long time (Wagmiller, Lennon, Kuang, Alberti, \& Aber, 2006). 
Much less is known about how the timing of economic disadvantage associates with early adult outcomes and very few studies have investigated how family income at different stages of child life impacts early adult wellbeing (see Kalil, Duncan, \& Ziol-Guest, 2016).

\section{Background}

Studies using both survey and register data from several cultural contexts and welfare state regimes have documented the detrimental short- and longterm impact of childhood poverty (for a systematic review of mental health outcomes, see Reiss, 2013). For example, several British cohort studies have documented the short- and long-term consequences of poverty on child development, including the most recent Millennium Cohort (Dickerson \& Popli, 2016). Najman and colleagues (2009) in Australia showed, using a populationbased prospective birth cohort study, that being exposed to poverty at four different measurement points was associated with the worst outcomes in terms of cognitive development. Each additional exposure to poverty between birth and age 14 was associated with an additional decline in the score on Raven's Standard Progressive Matrices by 2.19 units. Duncan and colleagues (Duncan, Telle, ZiolGuest, \& Kalil, 2010), using data from the US, measured poverty across several distinct periods of childhood, distinguishing family income in early childhood from income in middle childhood and adolescence. They found that, compared with children whose families had incomes of at least twice the poverty line during their early childhood, poor children completed two fewer years of schooling, earned less than half the salaries of their more affluent counterparts, worked fewer hours, and received more food stamps as adults. Males who grew up in poverty were found to be arrested more often and females' poverty in early childhood was associated with teenage pregnancy. Genderspecific effects of poverty have been reported in a number of studies, but in her systematic review, Reiss (2013) concludes that, in terms of mental health outcomes, no consistent patterns can be identified. Gibb, Fergusson and Horwood (2012) reported from New Zealand that declining childhood family income was associated with a range of negative outcomes in adulthood, including lower educational achievement, poorer economic circumstances, higher rates of criminal offending, mental health problems and teenage pregnancy.
After covariate adjustment, childhood family income remained significantly associated with educational achievement and economic circumstances, but was no longer significantly associated with mental health, offending and teenage pregnancy outcomes. Other research has also acknowledged the differential effect of childhood poverty on cognitive ability and emotional adjustment. For example, in their early work, Brooks-Gunn and Duncan (1997) showed that childhood poverty had the largest impact on children's ability and achievement and a smaller impact on emotional development.

A recent study from Norway showed that low income experienced in early childhood correlates with the chances of later-life economic success (Duncan, Telle, Ziol-Guest, \& Kalil, 2010). In Sweden, children in families receiving long-term social assistance showed considerably less satisfactory future prospects regarding healthrelated outcomes, educational attainment and social assistance receipt in young adulthood compared with the rest of the population, and also in comparison with other low-income individuals (Weitoft, Hjern, Batljan, \& Vinnerljung, 2008). Similar findings have also been made in nonWestern countries. For example, Pakpahan, Suryadarm and Suryahadi (2009) showed that in Indonesia, children exposed to recurrent poverty in childhood were $31 \%$ more likely to be poor adults than their more affluent childhood counterparts.

\section{Theoretical models explaining the effect of poverty on later outcomes}

The most widely accepted explanation for the detrimental effect of childhood poverty on adult wellbeing assumes that low income, poverty and material deprivation lead to a series of barriers that limit the development and life course opportunities of those reared in low-income families. Low family income and welfare receipt has been argued to influence children's future success and achievements through parents' material and emotional endowments and investment with their children (Becker, 1991). Broadly speaking, this model suggests that child development is produced as a result of genetic endowments and the values and preferences parents pass on to their children, together with different types of resource, such as time. Recent evidence from the United States has shown that the key driver behind diverging destinies of rich and poor children in terms of 
cognitive and non-cognitive skills is the behaviour, and in particular the engagement, of parents with their children at home (Mayer, Kalil, Oreopoulos, \& Gallegos, 2015). Several US studies have shown that more affluent parents engage more often and for longer periods of time in behaviours such as reading that stimulate the cognitive and non-cognitive development of their children, than their less affluent peers do, leading to sizable differences in their children's outcomes (Cunha, Heckman, Lochner, \& Masterov, 2006; Heckman \& Masterov, 2007).

Another theoretical model explains the impact of poverty through stress experienced within the family or surrounding environment (Elder, 1974; Kessler \& Cleary, 1980; McLeod \& Kessler, 1990). The distress caused by having to negotiate everyday challenges in the context of economic scarcity is seen to impact child development. Stress may act as a mediator explaining the association between childhood poverty and negative outcomes in adulthood (Winning, Glymour, McCormick, Gilsanz, \& Kubzansky, 2016). The impact of stress as a result of low income is also often exacerbated by cooccurring disruptions in family functioning (Solantaus, Leinonen, \& Punamäki, 2004). The stress model has recently been developed further by researchers in behavioural economics who have demonstrated that periods of economic scarcity lead to reductions in our cognitive resources that impact our ability to regulate our behaviour (Spears, 2011). Poverty, in essence, reduces our cognitive bandwidth, affecting our ability to make good choices for the future at the expense of more immediate benefits (Schilbach, Schofield, \& Mullainathan, 2016).

A third theoretical model explaining the negative impact of poverty on child development is one that considers selection effects (Mayer, 1997). When trying to isolate the effect of poverty on child development, researchers must consider the often co-occurring socioeconomic effects impacting child outcomes. Poor parents are often less educated and have lower socioeconomic status (SES) than their more affluent counterparts. Also, poor households are more often headed by a single breadwinner and more likely to experience mental health problems, or an accumulation of these challenges, which may have more than an additive negative impact on child development (Ben-Shlomo \& Kuh, 2002; Crystal \& Shea, 1990). Also the influence of often unmeasured effects, such as parental motivation or mental health, may have significant impact on child outcomes that non-experimental studies are unable to identify.

\section{Significance of timing of poverty}

Despite these earlier findings, it is not clear how significant the timing of childhood poverty is on early adult outcomes. Economic disadvantage in early childhood has been argued to be more detrimental to child development than disadvantage experienced during adolescence, because early childhood is the period in which children acquire cognitive and social competencies that form the basis of future wellbeing and academic success (Brooks-Gunn \& Duncan, 1997; Farkas \& Beron, 2004; Kalil, Ryan, \& Corey, 2012; Schoon et al., 2002). Also, in early childhood brain development is rapid and the brain may be more vulnerable to environmental stressors associated with poverty than it is later in life (Knudsen, Heckman, Cameron, \& Shonkoff, 2006). On the other hand, some evidence suggests that low income in adolescence rather than early childhood is associated with negative outcomes in young adulthood, because older children in low-income families may be more aware of their economically limited circumstances and their restricted opportunities for success, and as a result may reduce their aspirations and effort (Sobolewski \& Amato, 2005). In a chapter of the recent Handbook of the Life Course, Kalil and colleagues review the evidence regarding the short- and long-term impact of poverty and conclude that very little is known about the significance of the timing of the poverty (Kalil et al., 2016).

In our study we ask how does the timing of childhood economic disadvantage impact children's later adjustment and mental health. We operationalise economic disadvantage as parental receipt of social assistance and measure it at five different age periods: $0-2,3-6,7-12,13-16$, and $17+$. As previous research has conclusively indicated that long-term and persistent poverty has significantly more detrimental effects on child outcomes than transient or short-term poverty, we investigate the significance of timing among those families experiencing poverty for an extended period, more than four months.

The principal focus of the analysis is to examine whether early childhood poverty is more harmful for child development than economic disadvantage 
in later childhood. We measure child outcomes using several objective indicators of adjustment problems, as conceptualised by Schoon and Bartley (2008). Specifically, we measure early school leaving, teenage pregnancy, criminality, and mental health disorders before age 25. A major advantage of this study is that our data contain reliable measures of both social assistance receipt and correlated aspects of parental socioeconomic status, and indicators of parental mental health, and it is possible to estimate the separate contributions of each.

\section{Social assistance in Finland}

Social assistance is a means-tested last-resort form of income protection in Finland. It is granted only if the applicant has no other source of income, or the income is inadequate to meet the individual's or family's basic needs (Kuivalainen, 2013). Other benefits, such as child allowance and unemployment benefits reduce the level of social assistance. Only if the level of primary benefits and other sources of income are not adequate to cover the basic necessities such as food, shelter and medicine will social assistance be granted. Social assistance is meant to be a temporary benefit that fills gaps in income. Recipients of social assistance are often unemployed, single parenting or living alone, experiencing health problems and less educated than the Finnish populations on average (Kuivalainen, 2013).

Social assistance in Finland is considered a good indicator of poverty for several reasons. One reason is that in order to received social assistance one has to actively apply for it, which implies that the applicant has a subjective evaluation of need for the assistance. Another reason is that receiving social assistance requires a public authority to determine that a person's primary sources of income are inadequate to meet basic needs (Kangas \& Ritakallio, 2008). Altogether, $7.3 \%$ of the Finnish population received social assistance in 2015 and people increasingly received social assistance for longer periods of time (Official statistics of Finland, 2016). In Finland, students may qualify for social assistance if they do not find summer jobs and as a result, receive social assistance for two to three months. In the 1990s, Finland experienced a major economic recession and unemployment rose dramatically from 3.5 to $18.9 \%$. Children in the 1987 FBC were about four years of age when the recession began and approximately 13 when the recession finally ended. We tried to estimate potential selection among social assistance recipients in different timing groups using all our parental covariates, but were not able to identify any major sociodemographic or health differences that could explain differences in the child outcomes.

\section{Data and methods}

The 1987 Finnish Birth Cohort. The 1987 Finnish Birth Cohort is a register-based dataset that includes all 59,476 children born in the year 1987 in Finland and followed during the years 1987 to 2012 . The register data were combined using cohort members' and their parents' personal identification numbers (Paananen, Ristikari, \& Gissler, 2014). The institutional ethical review board at the National Institute for Health and Welfare (THL) gave a positive statement for the whole study (March 26, 2009, § 28/2009), and all register authorities gave permission to use their data.

\section{Variables \\ Social assistance receipt}

The main independent variable measures the incidence of social assistance receipt. The information of parental social assistance receipts were obtained from National Institute for Health and Welfare's registers. Parental social assistance was registered for either the biological mother, biological father or for both parents during the follow-up of 1987 to 2008 (child aged between 0 and 21). Parental social assistance was coded in three different ways: i) receipt (received or not); ii) duration (0 months, 1-3 months, and 4 months or more); and iii) duration $x$ age of child at first instance of social assistance receipt (0 months, 1-3 months, 4 months or more, when child was on age $0-2 / 3-6 / 7-12 / 13-16 / 17$ or more).

\section{Control variables}

In order to estimate the impact of social assistance receipt on early adulthood outcomes, we included a number of social background variables. As Mayer (1997) has argued, previous research has often been unable to control for the following family characteristics that may account for much of the observed association between social assistance receipt and child outcomes.

\section{Parental education}

Information on the highest educational achievements was received from Statistics Finland 
and was categorised in the variable "parents' highest education" as a binary variable, early school leaving vs. higher education. We categorised educational attainment by UNESCO's International Standard Classification of Education (ISCED), where early school leaving was set as having not completed ISCED level three education by the year 2008. In other words, our definition for early school leaving includes those who have not completed compulsory education which ends at age 16, those who have completed compulsory education at best and those who have entered secondary education (non-compulsory after age 16) but did not complete a programme of study.

\section{Parental SES}

The data on the socioeconomic status (SES) of the cohort members' biological parents were collected from the Finnish Central Population Register on June 10, 2009, and it included parents' most recent occupations: classified as upper whitecollar workers, lower white-collar workers, bluecollar workers, or 'others', including entrepreneurs, students, housewives and farmers. We considered the SES of both parents and chose the higher of the two. Residents of Finland are asked to report to the Central Population Register their occupation, and not all residents adhere to the regulation. Of the cohort member's parents, $1.9 \%$ have a missing value, which we have categorised as "missing".

\section{Other than nuclear family}

Data on cohort members' biological parents' mutual marriages and divorces and dates of death during the follow-up (1987-2008) were received from the Finnish Central Population Register. Data on mother's marital status at the time of cohort member's birth were collected from the Medical Birth Register (MBR), kept by THL. The variable 'other than nuclear family' was coded as a binary variable, yes/no, where 'yes' consisted of families where the mother of the cohort member was either not married at the time of the birth, either parent had died during the follow-up, or the cohort member's parents had divorced during the followup.

\section{Teenage pregnancy, cohort member's mother}

The Medical Birth Register (MBR) includes the information on the year and month of birth of the mother of the cohort member. Based on this information, the age of the mother at the time of giving birth to the cohort member was calculated. If the mother was less than 20 years at the time of the cohort member's birth, we gave value 1 , and value 0 for mothers who were older than 20 .

\section{Parental psychiatric in/outpatient care}

The variable "parental psychiatric in/outpatient" care was coded as a binary variable, yes/no, based on whether either parent had been treated in either inpatient (1987-2008) or outpatient (1998-2008) psychiatric care according to the data from the hospital discharge register kept by the National Institute for Health and Welfare, Finland.

To assess developmental outcomes during young adulthood, four outcome variables were measured: 1) early school leaving; 2) criminal record; 3) mental health disorders; and 4) teenage pregnancy. We used listwise deletion for missing values, except for parental SES where we coded for missing as a category. Table 1 shows the frequency distribution of all the measured variables by gender. Nine per cent of parents had received social assistance for short periods, less than three months, and about $29 \%$ more than four months. Four months was the median duration of social assistance receipt (not shown in table).

\section{Cohort members' early adult outcomes Early school leaving}

Information on the highest educational achievements until 2012 was received from Statistics Finland. We measured educational attainment by UNESCO's International Standard Classification of Education (ISCED), and considered early school leaving as having not completed ISCED level three education-or secondary education-by the end of year 2012, when cohort members turned 25 . In other words, our definition for early school leaving includes those who have not completed compulsory education, those who have completed compulsory education at best, and those who have entered secondary education but did not complete a programme of study.

\section{Criminal record}

The Finnish Legal Register Centre has a national central register of criminal records. The variable "criminal record" was created (binary, yes/no) from the information on criminal offending for which a court had imposed a conviction between 1987 and 2012. 
Table 1. Composition of the 1987 Finnish Birth Cohort for females and males

\begin{tabular}{|c|c|c|c|c|}
\hline & \multicolumn{2}{|l|}{ Females } & \multicolumn{2}{|l|}{ Males } \\
\hline & $\mathrm{n}$ & $\%$ & $\mathrm{~N}$ & $\%$ \\
\hline Number of births & \multicolumn{2}{|l|}{29,041} & \multicolumn{2}{|l|}{30,435} \\
\hline \multicolumn{5}{|l|}{ Variable } \\
\hline \multicolumn{5}{|l|}{ Cohort member outcomes: } \\
\hline Early school leaving & 4,688 & 16.1 & 6,296 & 20.7 \\
\hline Criminal record & 890 & 3.1 & 4,238 & 13.9 \\
\hline Mental health disorder & 3,699 & 12.7 & 2,816 & 9.3 \\
\hline Teenage pregnancy & 2,834 & 9.8 & - & - \\
\hline $\begin{array}{l}\text { Parent indicators: } \\
\text { Parent's highest education (early school leaving vs } \\
\text { higher) }\end{array}$ & 2,009 & 6.9 & 2,119 & 7.0 \\
\hline \multicolumn{5}{|l|}{ Parent's highest SES } \\
\hline Upper & 9,014 & 31.0 & 9,456 & 31.1 \\
\hline Lower & 11,811 & 40.7 & 12,401 & 40.7 \\
\hline Workers & 6,683 & 23.0 & 6,977 & 22.9 \\
\hline Other & 985 & 3.4 & 1,030 & 3.4 \\
\hline Unknown & 548 & 1.9 & 571 & 1.9 \\
\hline Other than nuclear family & 13,359 & 46.0 & 13,573 & 44.6 \\
\hline Teenage pregnancy, cohort member's mother & 933 & 3.2 & 974 & 3.2 \\
\hline Parental psychiatric in/outpatient care & 6,781 & 76.7 & 6,309 & 20.7 \\
\hline Parental social assistance receipt & 11,062 & 38.1 & 11,537 & 37.9 \\
\hline \multicolumn{5}{|l|}{ Parental social assistance, duration } \\
\hline 0 months & 17,979 & 61.9 & 18,898 & 62.1 \\
\hline $1-3$ months & 2,560 & 8.8 & 2,765 & 9.1 \\
\hline 4 months or more & 8,502 & 29.3 & 8,772 & 28.8 \\
\hline \multicolumn{5}{|l|}{ Parental social assistance, duration $\mathrm{x}$ age } \\
\hline 4 months or more, child on age $0-2$ & 4,158 & 14.3 & 4,304 & 14.1 \\
\hline 4 months or more, child on age $3-6$ & 2,517 & 8.7 & 2,600 & 8.5 \\
\hline 4 months or more, child on age $7-12$ & 1,343 & 4.6 & 1,393 & 4.6 \\
\hline 4 months or more, child on age $13-16$ & 334 & 1.2 & 304 & 1.0 \\
\hline 4 months or more, child on age 17 or more & 150 & 0.5 & 171 & 0.6 \\
\hline
\end{tabular}




\section{Mental health disorder}

Cohort member's mental health was studied by creating a variable 'mental health disorder', which was coded as a binary variable, yes/no, based on whether according to the Finnish Hospital Discharge Register (HDR), the cohort member had been given a mental or behavioural disorders diagnosis between 1987 and 2012 (ICD-9: 290-319, ICD-10: F00-99) based on International Classification of Diseases 9th Revision (ICD-9) or ICD-10 codes.

\section{Teenage pregnancy}

Based on this information from the MBR, the age of the female cohort member at the time of giving birth for the first time was calculated, and we gave a value of one for those who have given birth prior to age 20 .

\section{Statistical methods}

Frequency distributions of the parental social assistance variables and control variables with percentages by child outcomes were calculated for females and males, and are shown in table 2. In model 1, using logistic regression, we estimated bivariate associations between parental social assistance receipt and all four dependent variables separately for females and males (table 3), replicating earlier findings about the association of childhood poverty on negative early adult outcomes.

In model 2, we categorised parental social assistance receipt for two different durations (1-3 months and more than 4 months) and adjusted with other related family sociodemographic variables (education, SES, non-nuclear family, teenage pregnancy) and psychiatric care.

In model 3, we estimated the odds ratios for all the outcome variables within five separate age categories $(0-2,3-6,7-12,13-16,17+)$ for those who had received social assistance for at least four months, to estimate the impact of timing of social assistance receipt, while adjusting for the same parent-related covariate as in model 2 . The results of model 3 are shown in table 5 . All statistical analyses were performed using IBM SPSS Statistics, version 22.

\section{Results}

Almost $38 \%$ of parents received social assistance during the first 21 years of the cohorts' lives; 11,062 female (38.1\%) and 11,537 male (37.9\%) cohort members had a parent who had received social assistance. Furthermore, the outcome measures were closely associated with parental social assistance receipt. As shown in table 2, over $60 \%$ of the cohort members who left school early had a parent who had received social assistance ( $66 \%$ for females and 60.8 for males). Of the female cohort members who had a criminal record, $68.8 \%$ had a parent who had received social assistance $(58.3 \%$ for males). Also, of the male cohort members with a mental health disorders, $58.3 \%$ had a parent who had received social assistance (53.8\% for females).

Table 3 also shows the unadjusted odds ratios from the logistic regression models estimating the association between parental social assistance receipt and cohort members' early adult outcomes. Parental social assistance receipt increased the risk for all the studied child outcomes significantly. Parental social assistance increased the risk for early school leaving three to four times (OR 4.00 for females, 3.30 for males), and criminal records almost four times for females (3.73) and almost two and a half times for males (2.47). The OR for mental disorders for females was 2.09, and for males 2.51. Furthermore, parental social assistance receipt increased the risk for teenage pregnancy by 2.85 . Females' ORs were larger than those of males, except for mental disorders.

Table 4 shows the adjusted ORs for two categories of parental social assistance receipt duration (1-3 months and 4+ months) by gender (model 2). The impact of the length of social assistance receipt is clear. Our results show that the highest risks for all negative outcomes were found when parental social assistance receipt had lengthened (4+ months), even though both of the different length categories were statistically significant. When parental social assistance receipt had lasted for 4 months or longer, the OR for early school leaving was 3.07 for females and 2.63 for males, the OR for criminal record was 2.45 for females and 1.98 for males, for mental health disorder the OR was 1.77 for females and 1.90 for males, and the OR for teenage pregnancy for females was 2.36. According to our results, childhood poverty associated more negatively with female outcomes. When childhood poverty was more transient, gender differences in outcomes were almost inexistent. A low level of parent educational attainment was also associated with an increased risk for all negative outcomes, with females showing larger ORs for early school leaving (female 2.04 and male 1.99) and criminal record 


\section{Table 2. Composition of dependent variables for females and males}

\begin{tabular}{|c|c|c|c|c|c|c|c|c|c|c|c|c|c|c|}
\hline \multirow[b]{3}{*}{ Variable (parental indicators) } & \multicolumn{4}{|c|}{ Early school leaving } & \multicolumn{4}{|c|}{ Criminal record } & \multicolumn{4}{|c|}{ Mental health disorder } & \multirow{2}{*}{\multicolumn{2}{|c|}{$\begin{array}{l}\begin{array}{l}\text { Teenage } \\
\text { pregnancy }\end{array} \\
\text { Females } \\
\end{array}$}} \\
\hline & \multicolumn{2}{|c|}{ Females } & \multicolumn{2}{|l|}{ Males } & \multicolumn{2}{|c|}{ Females } & \multicolumn{2}{|l|}{ Males } & \multicolumn{2}{|c|}{ Females } & \multicolumn{2}{|l|}{ Males } & & \\
\hline & $\mathrm{n}$ & $\%$ & $\mathrm{n}$ & $\%$ & $\mathrm{n}$ & $\%$ & $\mathrm{n}$ & $\%$ & $\mathrm{n}$ & $\%$ & $\mathrm{n}$ & $\%$ & $\mathrm{n}$ & $\%$ \\
\hline Number of births & \multicolumn{2}{|l|}{4,688} & \multicolumn{2}{|l|}{6,296} & \multicolumn{2}{|l|}{890} & \multicolumn{2}{|l|}{4,238} & \multicolumn{2}{|l|}{3,699} & \multicolumn{2}{|l|}{2,816} & \multicolumn{2}{|l|}{2,834} \\
\hline $\begin{array}{l}\text { Parent's highest education (early school } \\
\text { leaving vs highest) }\end{array}$ & 709 & 15.1 & 862 & 13.7 & 158 & 17.8 & 530 & 12.5 & 374 & 10.1 & 299 & 10.6 & 374 & 13.0 \\
\hline \multicolumn{15}{|l|}{ Parent's highest SES } \\
\hline Upper & 841 & 17.9 & 1,367 & 21.7 & 145 & 16.3 & 848 & 20.0 & 1,037 & 28.0 & 772 & 27.4 & 486 & 17.0 \\
\hline Lower & 1,866 & 39.8 & 2,482 & 39.4 & 338 & 38.0 & 1,745 & 41.2 & 1,437 & 38.8 & 1,044 & 37.1 & 1,166 & 40.7 \\
\hline Workers & 1,645 & 35.1 & 3,041 & 32.4 & 337 & 37.9 & 1,404 & 33.1 & 1,015 & 27.4 & 841 & 29.9 & 1,023 & 35.7 \\
\hline Other & 223 & 4.8 & 270 & 4.3 & 49 & 5.5 & 163 & 3.8 & 143 & 3.9 & 117 & 4.2 & 131 & 4.6 \\
\hline Unknown & 113 & 2.4 & 136 & 2.2 & 21 & 2.4 & 78 & 1.8 & 67 & 1.8 & 42 & 1.5 & 61 & 2.1 \\
\hline Other than nuclear family & 3,152 & 67.2 & 4,002 & 63.6 & 632 & 71.0 & 2,631 & 62.1 & 2,269 & 61.3 & 1,749 & 62.1 & 1,863 & 65.0 \\
\hline Teenage pregnancy & 346 & 7.4 & 418 & 6.6 & 79 & 8.9 & 292 & 6.9 & 197 & 5.3 & 180 & 6.4 & 237 & 8.3 \\
\hline Parental psychiatric in/outpatient care & 1,365 & 29.1 & 1,670 & 26.5 & 282 & 31.7 & 1,133 & 26.7 & 1,167 & 31.5 & 976 & 34.7 & 831 & 29.0 \\
\hline Parental social assistance, receipt & 3,095 & 66.0 & 3,826 & 60.8 & 612 & 68.8 & 2,469 & 58.3 & 1,991 & 53.8 & 1,642 & 58.3 & 1,789 & 62.4 \\
\hline \multicolumn{15}{|l|}{ Parental social assistance, duration } \\
\hline 0 months & 1,593 & 34.0 & 2,470 & 39.2 & 278 & 31.2 & 1,769 & 41.7 & 1,708 & 46.2 & 1,174 & 41.7 & 1,078 & 37.6 \\
\hline $1-3$ months & 438 & 9.3 & 639 & 10.1 & 70 & 7.9 & 417 & 9.8 & 328 & 8.9 & 245 & 8.7 & 270 & 9.4 \\
\hline 4 months or more & 2,657 & 56.7 & 3,187 & 50.6 & 542 & 60.9 & 2,052 & 48.4 & 1,663 & 45.0 & 1,397 & 49.6 & 1,519 & 53.0 \\
\hline \multicolumn{15}{|l|}{ Parental social assistance, duration $\mathrm{x}$ age } \\
\hline 4 months or more, child on age $0-2$ & 1,587 & 33.9 & 1,816 & 28.8 & 354 & 39.8 & 1,191 & 28.1 & 914 & 24.7 & 781 & 27.7 & 910 & 31.7 \\
\hline 4 months or more, child on age $3-6$ & 636 & 13.6 & 840 & 13.3 & 118 & 13.3 & 549 & 13.0 & 426 & 11.5 & 379 & 13.5 & 376 & 13.1 \\
\hline 4 months or more, child on age $7-12$ & 324 & 6.9 & 417 & 6.6 & 43 & 4.8 & 239 & 5.6 & 240 & 6.5 & 178 & 6.3 & 179 & 6.2 \\
\hline 4 months or more, child on age $13-16$ & 72 & 1.5 & 74 & 1.2 & 19 & 2.1 & 47 & 1.1 & 59 & 1.6 & 35 & 1.2 & 39 & 1.4 \\
\hline 4 months or more, child on age 17 or more & 38 & 0.8 & 40 & 0.6 & 8 & 0.9 & 26 & 0.6 & 24 & 0.6 & 24 & 0.9 & 15 & 0.5 \\
\hline
\end{tabular}


Table 3. Model 1 - unadjusted odds ratios with $95 \%$ confidence intervals by dependent variables for females and males




Table 4. Model 2 with two categories for length of parental social assistance - adjusted odds ratios with $95 \%$ confidence intervals by dependent variables for females and males

\begin{tabular}{|c|c|c|c|c|c|c|c|c|c|c|c|c|c|c|}
\hline \multirow[b]{3}{*}{ Variables } & \multicolumn{4}{|c|}{ Early school leaving } & \multicolumn{4}{|c|}{ Criminal record } & \multicolumn{4}{|c|}{$\begin{array}{l}\text { Mental health } \\
\text { disorder }\end{array}$} & \multirow{2}{*}{\multicolumn{2}{|c|}{$\begin{array}{l}\begin{array}{l}\text { Teenage } \\
\text { pregnancy }\end{array} \\
\text { Females }\end{array}$}} \\
\hline & \multicolumn{2}{|c|}{ Females } & \multicolumn{2}{|l|}{ Males } & \multicolumn{2}{|l|}{ Females } & \multicolumn{2}{|l|}{ Males } & \multirow{2}{*}{$\frac{\text { Females }}{\text { OR }}$} & \multirow[b]{2}{*}{$95 \% \mathrm{Cl}$} & \multicolumn{2}{|l|}{ Males } & & \\
\hline & OR & $95 \% \mathrm{Cl}$ & OR & $95 \% \mathrm{Cl}$ & OR & $95 \% \mathrm{Cl}$ & OR & $95 \% \mathrm{Cl}$ & & & OR & $95 \% \mathrm{Cl}$ & OR & $95 \% \mathrm{Cl}$ \\
\hline $\begin{array}{l}\text { Parental social } \\
\text { assistance, } \\
\text { duration ( } 0 \text { months } \\
\text { ref) }\end{array}$ & 1.00 & & 1.00 & & 1.00 & & 1.00 & & 1.00 & & 1.00 & & 1.00 & \\
\hline $1-3$ months & $1.63^{*}$ & $1.41-1.88$ & $1.73 *$ & $1.55-1.93$ & $1.38^{*}$ & $1.11-1.72$ & $1.36^{*}$ & $1.23-1.52$ & $1.26^{*}$ & $1.13-1.41$ & $1.27 *$ & $1.13-1.43$ & $1.55^{*}$ & $1.36-1.77$ \\
\hline 4 months or more & $3.07 *$ & $2.79-3.38$ & $2.63 *$ & $2.43-2.84$ & $2.45^{*}$ & $2.12-2.83$ & $1.98^{*}$ & $1.84-2.13$ & $1.77^{*}$ & $1.64-1.91$ & $1.90 *$ & $1.76-2.06$ & $2.36^{*}$ & $2.16-2.59$ \\
\hline $\begin{array}{l}\text { Parent's highest } \\
\text { education } \\
\text { (early school leaving } \\
\text { vs higher) } \\
\text { Parent's highest SES } \\
\text { (upper as ref.) }\end{array}$ & $2.04 *$ & $1.82-2.29$ & $1.99 *$ & $1.79-2.20$ & $1.73^{*}$ & $1.47-2.03$ & $\begin{array}{l}1.48^{*} \\
1.00\end{array}$ & $1.33-1.64$ & $1.22 *$ & $1.10-1.37$ & $1.26 *$ & L.13-1.42 & $1.32 *$ & $1.17-1.48$ \\
\hline Lower & $1.22^{*}$ & $1.10-1.36$ & $1.21 *$ & $1.11-1.31$ & $1.43^{*}$ & $1.21-1.69$ & $1.36^{*}$ & $1.25-1.47$ & $0.92 *$ & $0.85-0.99$ & 0.94 & $0.87-1.02$ & $1.58^{*}$ & $1.42-1.75$ \\
\hline Workers & $1.65^{*}$ & $1.47-1.85$ & $1.61 *$ & $1.46-1.76$ & $1.91 *$ & $1.60-2.27$ & $1.65^{*}$ & $1.52-1.80$ & 0.99 & $0.90-1.07$ & 1.08 & $0.98-1.18$ & $2.08 *$ & $1.86-2.32$ \\
\hline Other & $1.59 *$ & $1.31-1.94$ & $1.41 *$ & $1.18-1.67$ & $1.86^{*}$ & $1.39-2.48$ & $1.29 *$ & $1.09-1.52$ & 0.99 & $0.84-1.17$ & 1.01 & $0.85-1.21$ & $1.87^{*}$ & $1.54-2.28$ \\
\hline $\begin{array}{l}\text { Unknown } \\
\text { Other than nuclear } \\
\text { family }\end{array}$ & $1.80^{*}$ & $1.38-2.35$ & $1.57^{*}$ & $1.25-1.98$ & $1.54^{*}$ & $1.01-2.36$ & $1.27^{*}$ & $1.01-1.59$ & 0.95 & $0.76-1.19$ & 0.93 & $0.73-1.19$ & $1.82^{*}$ & $1.40-2.37$ \\
\hline $\begin{array}{l}\text { Teenage pregnancy } \\
\text { Parental psychiatric }\end{array}$ & $1.39 *$ & $1.18-1.62$ & $1.36^{*}$ & $1.17-1.56$ & $1.55^{*}$ & $1.26-1.91$ & $1.47^{*}$ & $1.28-1.69$ & $1.19 *$ & $1.02-1.38$ & $1.21 *$ & $1.03-1.41$ & $1.74 *$ & $1.50-2.02$ \\
\hline in/outpatient care & 1.00 & $0.91-1.09$ & 1.02 & $0.95-1.10$ & 1.08 & $0.95-1.22$ & $1.10^{*}$ & $1.01-1.17$ & $1.32 *$ & $1.23-1.41$ & $1.58^{*}$ & $1.47-1.70$ & 1.03 & $0.95-1.12$ \\
\hline
\end{tabular}

$\mathrm{OR}$, odds ratio; $\mathrm{Cl}$, confidence interval, * indicates statistical significance $(<0.05)$ 
Table 5. Model 3 with length and age of parental social assistance - adjusted odds ratios with $95 \%$ confidence intervals by dependent variables for females and males

\begin{tabular}{|c|c|c|c|c|c|c|c|c|c|c|c|c|c|c|}
\hline \multirow[b]{3}{*}{ Variable } & \multicolumn{4}{|c|}{ Early school leaving } & \multicolumn{4}{|c|}{ Criminal record } & \multicolumn{4}{|c|}{ Mental health disorder } & \multirow{2}{*}{\multicolumn{2}{|c|}{$\begin{array}{l}\text { Teenage pregnanc } \\
\text { Females }\end{array}$}} \\
\hline & \multicolumn{2}{|c|}{ Females } & \multicolumn{2}{|l|}{ Males } & \multicolumn{2}{|c|}{ Females } & \multicolumn{2}{|l|}{ Males } & \multicolumn{2}{|c|}{ Females } & \multicolumn{2}{|l|}{ Males } & & \\
\hline & OR & $95 \% \mathrm{Cl}$ & OR & $95 \% \mathrm{Cl}$ & OR & $95 \% \mathrm{Cl}$ & OR & $95 \% \mathrm{Cl}$ & OR & $95 \% \mathrm{Cl}$ & OR & $95 \% \mathrm{Cl}$ & OR & $95 \% \mathrm{Cl}$ \\
\hline $\begin{array}{l}\text { Parental social } \\
\text { assistance, duration } \mathrm{x} \\
\text { age ( } 0 \text { months ref.) }\end{array}$ & 1.00 & & 1.00 & & 1.00 & & 1.00 & & 1.00 & & 1.00 & & 1.00 & \\
\hline $\begin{array}{l}1-3 \text { months } \\
4 \text { months or more, }\end{array}$ & $1.65^{*}$ & $1.43-1.90$ & $1.74 *$ & $1.56-1.94$ & $1.41 *$ & $1.13-1.75$ & $1.37^{*}$ & $1.23-1.53$ & $1.27 *$ & $1.14-1.42$ & $1.28 *$ & $1.14-1.44$ & $1.56^{*}$ & $1.37-1.78$ \\
\hline $\begin{array}{l}\text { child on age } 0-2 \\
4 \text { months or more, }\end{array}$ & $3.90 *$ & $3.50-4.35$ & $3.19 *$ & $2.91-3.50$ & $3.27^{*}$ & $2.78-3.84$ & $2.38^{*}$ & $2.18-2.60$ & $2.07^{*}$ & $1.89-2.27$ & $2.13^{*}$ & $1.93-2.35$ & $2.92^{*}$ & $2.62-3.25$ \\
\hline $\begin{array}{l}\text { child on age } 3-6 \\
4 \text { months or more, }\end{array}$ & $2.51^{*}$ & $2.21-2.86$ & $2.33^{*}$ & $2.09-2.59$ & 1.99* & $1.63-2.42$ & $1.86^{*}$ & $1.67-2.06$ & $1.54 *$ & $1.39-1.72$ & $1.82 *$ & $1.63-2.03$ & $2.05^{*}$ & $1.81-2.33$ \\
\hline & $2.41 *$ & $2.05-2.84$ & $2.24^{*}$ & $1.95-2.57$ & $1.39 *$ & $1.05-1.85$ & $1.54 *$ & $1.34-1.77$ & $1.62 *$ & $1.41-1.85$ & $1.64 *$ & $1.42-1.89$ & $1.93^{*}$ & $1.64-2.26$ \\
\hline $\begin{array}{l}\text { child on age } 13-16 \\
4 \text { months or more, } \\
\text { child on age } 17 \text { or }\end{array}$ & $2.31 *$ & $1.71-3.13$ & $1.43^{*}$ & $1.06-1.93$ & $2.38^{*}$ & $1.56-3.62$ & 1.12 & $0.83-1.50$ & $1.43^{*}$ & $1.10-1.86$ & 1.3 & $0.96-1.75$ & $1.62^{*}$ & $1.18-2.22$ \\
\hline more & $3.03 *$ & $2.02-4.55$ & $1.64 *$ & $1.12-2.41$ & 1.77. & $0.89-3.52$ & 1.32 & $0.91-1.92$ & 1.37 & $0.93-2.02$ & $1.94 *$ & $1.36-2.77$ & 1.3 & $0.79-2.15$ \\
\hline $\begin{array}{l}\text { Parent's highest } \\
\text { education (early } \\
\text { school leaving vs } \\
\text { higher) }\end{array}$ & $1.95^{*}$ & $1.73-$ & $1.93 *$ & $1.74-2.14$ & $1.62 *$ & $1.38-1.91$ & $1.43 *$ & $1.29-1.59$ & $1.19 *$ & $1.06-1.33$ & $1.24 *$ & $1.11-1.39$ & $1.26^{*}$ & $1.12-1.42$ \\
\hline $\begin{array}{l}\text { Parent's highest SES } \\
\text { (Upper as ref.) }\end{array}$ & 1.00 & & 1.00 & & 1.00 & & 1.00 & & 1.00 & & 1.00 & & 1.00 & \\
\hline Lower & $1.22^{*}$ & $1.09-1.35$ & $1.20 *$ & $1.11-1.31$ & $1.42 *$ & $1.20-1.68$ & $1.35^{*}$ & $1.25-1.46$ & $0.92 *$ & $0.85-0.99$ & 0.94 & $0.86-1.01$ & $1.57^{*}$ & $1.42-1.74$ \\
\hline Workers & $1.56^{*}$ & $1.42-1.79$ & $1.57^{*}$ & $1.43-1.73$ & $1.82 *$ & $1.53-2.17$ & $1.63 *$ & $1.49-1.77$ & 0.97 & $0.89-1.06$ & 1.07 & $0.97-1.17$ & $2.02 *$ & $1.81-2.26$ \\
\hline Other & $1.55^{*}$ & $1.27-1.90$ & $1.37 *$ & $1.16-1.63$ & $1.80 *$ & $1.35-2.41$ & $1.26 *$ & $1.06-1.49$ & 0.98 & $0.83-1.15$ & 1 & $0.84-1.20$ & $1.84^{*}$ & $1.51-2.24$ \\
\hline Unknown & $1.75^{*}$ & $1.34-2.28$ & $1.54^{*}$ & $1.22-1.93$ & 1.48 & $0.97-2.27$ & 1.24 & $0.98-1.56$ & 0.94 & $0.74-1.18$ & 0.92 & $0.72-1.18$ & $1.78^{*}$ & $1.36-2.32$ \\
\hline $\begin{array}{l}\text { Other than nuclear } \\
\text { family }\end{array}$ & $1.62 *$ & $1.48-1.77$ & $1.72 *$ & $1.60-1.85$ & $1.58^{*}$ & $1.38-1.82$ & $1.51^{*}$ & $1.41-1.61$ & $1.39 *$ & $1.30-1.49$ & $1.33^{*}$ & $1.23-1.43$ & $1.31^{*}$ & $1.20-1.43$ \\
\hline $\begin{array}{l}\text { Teenage pregnancy } \\
\text { Parental psychiatric }\end{array}$ & $1.26^{*}$ & $1.07-1.47$ & $1.25^{*}$ & $1.08-1.44$ & $1.37 *$ & $1.11-1.70$ & $1.36^{*}$ & $1.18-1.56$ & 1.11 & $0.95-1.30$ & 1.15 & $0.98-1.34$ & $1.59 *$ & $1.36-1.85$ \\
\hline in/outpatient care & 0.98 & $0.90-1.07$ & 1.02 & $0.94-1.10$ & 1.06 & $0.93-1.20$ & $1.09 *$ & $1.01-1.17$ & $1.31^{*}$ & $1.22-1.40$ & $1.58^{*}$ & $1.47-1.70$ & 1.02 & $0.94-1.11$ \\
\hline
\end{tabular}

$\mathrm{OR}$, odds ratio; $\mathrm{Cl}$, confidence interval, * indicates statistical significance $(<0.05)$ 
(female 1.73 and male 1.48). Family instability associated most significantly with early school leaving among males (OR 1.73) and parental psychiatric care with male mental health disorders (OR 1.58). Gender differences in the covariate associations with the outcome measures were largely smaller than those associated with parental social assistance receipt.

When evaluating the impact of long-term parental social assistance receipt at different ages of the birth cohort members' lives, the results indicate the highest risk when the cohort member was less than two years of age (table 5 , model 3 ). For all the early adult outcomes studied, the highest odds ratios were found in the age category 0-2 years of age (early school leaving females: OR 3.90, males: OR 3.19; criminal record females: OR 3.27, males: OR 2.38; mental health disorders females: OR 2.07, males: OR 2.13; and teenage pregnancy: OR 2.92). In the age category of more than 17 years of age, the only significant outcome for females was early school leaving, and for males, early school leaving and mental health disorders. For the criminal record outcome, the second highest period of risk for females was in the age category 13-16 years of age (OR 2.38) and for males, 3-6 years of age (OR 1.86). For the mental health disorders outcome, the second highest period of risk for females was in the age category 7-12 years of age (OR 1.62), and for males, more than 17 years of age (OR 1.94). For the adolescent years, each successive age category had a slightly lower risk than the previous one. In terms of gender differences, all age categories for females associated with higher odds ratios than for males for early school leaving and criminal record. For the mental health disorder outcome, gender differences were mainly absent with the exception of age category $17+$ where males had an OR 1.94 and females a nonstatistically significant OR 1.37 .

\section{Discussion}

Decades of research have documented the negative impact of childhood poverty on later wellbeing. This paper examined the association between parents' social assistance receipt and early adult outcomes using register data from Finland. We were especially interested in how the timing of social assistance receipt associated with early adult outcomes.

Results of our study show that parental social assistance receipt during childhood increases the risk of all measured negative adjustment outcomes: early school leaving, criminality, mental health, and wellbeing problems in early adulthood. Most detrimental effects of social assistance receipt were found when parents received social assistance for a long period, more than four months compared to more transient one- to three-month periods. These results are consistent with previous results that long-term social assistance receipt is more harmful than short-term for child development (Duncan \& Yeung, 1995). Furthermore, according to the results, the impact of social assistance receipt was highest when the child was less than two years of age when the family received social assistance for the first time. Our finding is supported also by the recent study by Kalil and colleagues (2016), which suggested that poverty during the first five years of life poses the largest risk for children's development. Our results suggest that in fact, the first two years of life may be most crucial. The present study builds on the key conclusion that social assistance receipt in early childhood appears to matter more for shaping later development than economic conditions during adolescence. Early childhood is a developmental period that may be especially sensitive to environmental conditions affected by family income and early courses of development may reach well into adulthood.

We also found some gender differences. Our results indicate that females are more at risk from socioeconomic factors, while males are more affected by family instability and ill health. Previous research regarding gender differences has been inconclusive; as such, our results add to the evidence that gender differences may in fact be significant. Our results also support earlier research (Brooks-Gunn \& Duncan, 1997) that argues poverty is more harmful for cognitive development than emotional outcomes. We show that at all ages in childhood, poverty associates most negatively with early school leaving and less severely with criminality, mental health, and teenage pregnancy.

The present study has both strengths and limitations. A major advantage of this total birth cohort study with 25-year follow-up is that it can simultaneously identify the children's age period during which they were exposed to poverty for the first time and the duration of that exposure, and adjust for several previously identified risk factors. The data contain reliable measures of both social assistance receipt and correlated aspects of 
parental socioeconomic status and it is possible to estimate the separate contributions of each. Due to data limitations, previous research has often not been able to include all the necessary control variables, in particular family SES and parental mental health (Mayer, 1997). Furthermore, many survey studies related to social assistance receipt often have difficulties reaching exactly those who are at most risk, as willingness to take part in research is related to SES and, as a result, often those with low SES are under-represented in surveys. The data used here are based on Finnish national registers, which provide virtually complete datasets and thus are not biased by selective attrition.

The limitations of the study include the fact that the findings reflect the experiences of a single cohort of young people studied in a particular social context and over a specific historical period. Finnish children born in 1987 grew up during the recession of the 1990s, when large numbers of families faced unemployment and financial difficulties. Although we could not identify any significant differences in the sociodemographic distribution of the families experiencing poverty for the first time at different ages of the cohort members, it may be that we suffer from an omitted variable bias, and in fact, some other factors explain the associations we have identified. The results of our study should be replicated with other cohorts, born and raised during different economic cycles. Another limitation of our study is that some of the parent indicators may coincide with the child outcomes, which poses a risk of reverse causality. Future studies with updated register linkages that allow for completely separate follow-up windows for parental indicators and child outcomes should test for this potential limitation.

Despite these limitations, the study findings provide clear evidence of linkages between social assistance receipt during childhood and early adult outcomes, and suggest that the earlier years of a child's life are most sensitive to the environmental effects such as those associated with poverty.

\section{Funding}

The authors thank the Alli Paasikivi Foundation, the Emil Aaltonen Foundation, the Academy of Finland (grant number 288960 and PSYCHORTS consortium), and the National Institute for Health and Welfare for the financial support for the research.

\section{References}

Becker, G. S. (1991). A treatise on the family. Cambridge, Mass: Harvard University Press.

Ben-Shlomo, Y., \& Kuh, D. (2002). A life course approach to chronic disease epidemiology: conceptual models, empirical challenges and interdisciplinary perspectives. International Journal of Epidemiology, 31(2), 285-293. https://doi.org/10.1093/ije/31.2.285

Brooks-Gunn, J., \& Duncan, G. J. (1997). The effects of poverty on children. The Future of Children, 7(2,) 5571. https://doi.org/10.2307/1602387

Crystal, S., \& Shea, D. (1990). Cumulative advantage, cumulative disadvantage, and inequality among elderly people. The Gerontologist, 30(4), 437-443. https://doi.org/10.1093/geront/30.4.437

Cunha, F., Heckman, J. J., Lochner, L., \& Masterov, D. V. (2006). Interpreting the evidence on life cycle skill formation. Handbook of the Economics of Education, 1, 697-812. https://doi.org/10.1016/S1574$\underline{0692(06) 01012-9}$

Dickerson, A., \& Popli, G. K. (2016). Persistent poverty and children's cognitive development: evidence from the UK Millennium Cohort Study. Journal of the Royal Statistical Society: Series A (Statistics in Society), 179(2), 535-558. https://doi.org/10.1111/rssa.12128

Duncan, G. J., \& Yeung, W. J. J. (1995). Extent and consequences of welfare dependence among America's children. Children and Youth Services Review, 17(1-2), 157-182. https://doi.org/10.1016/01907409(95)00007-Y

Duncan, G. J., \& Brooks-Gunn, J. (Eds.). (1999). Consequences of growing up poor. New York, NY: Russell Sage Foundation. 
Duncan, G. J., \& Brooks-Gunn, J. (2000). Family poverty, welfare reform, and child development. Child development, 71(1), 188-196. https://doi.org/10.1111/1467-8624.00133

Duncan, G. J., Ziol-Guest, K. M., \& Kalil, A. (2010). Early-childhood poverty and adult attainment, behavior, and health. Child Development, 81(1), 306-325. https://doi.org/10.1111/j.1467-8624.2009.01396.x

Duncan, G., Telle, K., Ziol-Guest, K. \& Kalil, A. (2010). Economic deprivation on early childhood and adult attainment: comparative evidence from Norwegian registry data and the US panel study of income dynamics. In Smeeding, T. M., Erikson, R., \& Jäntti, M. (Eds.) Persistence, privilege, and parenting. The comparative study of intergenerational mobility. (pp.209-234). New York, NY: Russell Sage Foundation.

Elder Jr, G. H. (1974). Children of the Great Depression: Social Change in Life Experience. Chicago, IL: University of Chicago Press.

Farkas, G., \& Beron, K. (2004). The detailed age trajectory of oral vocabulary knowledge: Differences by class and race. Social Science Research, 33(3), 464-497. https://doi.org/10.1016/i.ssresearch.2003.08.001

Gibb, S. J., Fergusson, D. M., \& Horwood, L. J. (2012). Childhood family income and life outcomes in adulthood: findings from a 30-year longitudinal study in New Zealand. Social Science \& Medicine, 74(12), 1979-1986. https://doi.org/10.1016/i.socscimed.2012.02.028

Hansen, H. T. (2008). The dynamics of social assistance recipiency: Empirical evidence from Norway. European Sociological Review, 25(2), 215-231. https://doi.org/10.1093/esr/jcn040

Heckman, J. J., \& Masterov, D. V. (2007). The productivity argument for investing in young children. Applied Economic Perspectives and Policy, 29(3), 446-493. https://doi.org/10.3386/w13016

Holzer, H., Schanzenbach, D. W., Duncan, G. J., \& Ludwig, J. (2007). The economic costs of poverty in the United States: Subsequent effects of children growing up poor. Discussion Paper no. 1327-07. Institute for Research on Poverty. Retrieved from https://irp.wisc.edu/publications/dps/pdfs/dp132707.pdf

Ilmakunnas, I. (2018). Risk and vulnerability in social assistance receipt of young adults in Finland. International Journal of Social Welfare, 27(1), 5-16. https://doi.org/10.1111/ijsw.12273

Kalil, A., Duncan, G. J., \& Ziol-Guest, K. M. (2016). Early childhood poverty: Short and long-run consequences over the lifespan. In Handbook of the life course (pp. 341-354). Cham: Springer. https://doi.org/10.1007/978-3-319-20880-0 15

Kalil, A., Ryan, R., \& Corey, M. (2012). Diverging destinies: Maternal education and the developmental gradient in time with children. Demography, 49(4), 1361-1383. https://doi.org/10.1007/s13524-012$\underline{0129-5}$

Kangas, O., \& Ritakallio, V.-M. (2008). [Köyhyyden mittaustavat, sosiaaliturvan riittävyys ja köyhyyden yleisyys Suomessa]. Sosiaali- ja terveysturvan selosteita. No. 61. Helsinki.

Knudsen, E. I., Heckman, J. J., Cameron, J. L., \& Shonkoff, J. P. (2006). Economic, neurobiological, and behavioral perspectives on building America's future workforce. Proceedings of the National Academy of Sciences, 103(27), 10155-10162. https://doi.org/10.1073/pnas.0600888103

Kauppinen, T. M., Angelin, A., Lorentzen, T., Bäckman, O., Salonen, T., Moisio, P., \& Dahl, E. (2014). Social background and life-course risks as determinants of social assistance receipt among young adults in Sweden, Norway and Finland. Journal of European Social Policy, 24(3), 273-288. https://doi.org/10.1177/0958928714525818

Kessler, R. C., \& Cleary, P. D. (1980). Social class and psychological distress. American Sociological Review, 45(3), 463-478. https://doi.org/10.2307/2095178

Kuivalainen, S. (2013). Social assistance in the 2010 s. A study on social assistance clients and granting practices [Toimeentulotuki 2010-luvulla - Tutkimus toimeentulotuen asiakkuudesta ja myöntämiskäytännöistä]. National Institute for Health and Welfare (THL). Report 9/2013. Helsinki.

Mayer, S. E. (1997). What money can't buy: Family income and children's life chances. Cambridge, Mass.:Harvard University Press.

Mayer, S. E., Kalil, A., Oreopoulos, P., \& Gallegos, S. (2015). Using behavioral insights to increase parental engagement: The parents and children together (PACT) intervention (No. w21602). National Bureau of Economic Research. https://doi.org/10.3386/w21602 
McLeod, J. D., \& Kessler, R. C. (1990). Socioeconomic status differences in vulnerability to undesirable life events. Journal of Health and Social Behavior, 31(2), 162-172. https://doi.org/10.2307/2137170

McLoyd, V. C. (1998). Socioeconomic disadvantage and child development. American Psychologist, 53(2), 185. https://doi.org/10.1037/0003-066X.53.2.185

Najman, J. M., Hayatbakhsh, M. R., Heron, M. A., Bor, W., O'Callaghan, M. J., \& Williams, G. M. (2009). The impact of episodic and chronic poverty on child cognitive development. The Journal of Pediatrics, 154(2), 284-289.Nielsen, M. J., Juon, H. S., \& Ensminger, M. (2004). Preventing long-term welfare receipt: the theoretical relationship between health and poverty over the early life course. Social Science \& Medicine, 59(11), 2285-2301. https://doi.org/10.1016/j.jpeds.2008.08.052

Official Statistics of Finland, Social Protection (2016). Social assistance 2015 [e-publication). ISSN 1798-0887. Helsinki: National Institute for Health and Welfare, Finland [referred 12.6.2018]. Access method: https://www.julkari.fi/bitstream/handle/10024/131612/Tr19 16.pdf?sequence=4

Paananen R. \& Ristikari T. \& Gissler M. (2014) Young people's well-being in Finland in the light of the 1987 Finnish birth cohort. National Institute for Health and Welfare, THL 2014.

Pakpahan, Y. M., Suryadarma, D., \& Suryahadi, A. (2009). Destined for Destitution: Intergenerational Poverty Persistence in Indonesia. Chronic Poverty Research Centre Working Paper No. 134. https://doi.org/10.2139/ssrn.1531697

Reiss, F. (2013). Socioeconomic inequalities and mental health problems in children and adolescents: a systematic review. Social science \& medicine, 90, 24-31. https://doi.org/10.1016/i.socscimed.2013.04.026

Saraceno, C. (Ed.). (2002). Social assistance dynamics in Europe: national and local poverty regimes. Bristol, UK: Policy Press. https://doi.org/10.2307/i.ctt1t89hvw

Schoon, I., Bynner, J., Joshi, H., Parsons, S., Wiggins, R. D., \& Sacker, A. (2002). The influence of context, timing, and duration of risk experiences for the passage from childhood to midadulthood. Child Development, 73(5), 1486-1504. https://doi.org/10.1111/1467-8624.00485

Schoon, I., \& Bartley, M. (2008). The role of human capability and resilience. Psychologist, 21(1), 24-27.

Schilbach, F., Schofield, H., \& Mullainathan, S. (2016). The psychological lives of the poor. American Economic Review, 106(5), 435-440. https://doi.org/10.1257/aer.p20161101

Sobolewski, J. M., \& Amato, P. R. (2005). Economic hardship in the family of origin and children's psychological well-being in adulthood. Journal of Marriage and Family, 67(1), 141-156. https://doi.org/10.1111/i.0022-2445.2005.00011.x

Solantaus, T., Leinonen, J., \& Punamäki, R. L. (2004). Children's mental health in times of economic recession: replication and extension of the family economic stress model in Finland. Developmental Psychology, 40(3), 412-429. https://doi.org/10.1037/0012-1649.40.3.412

Spears, D. (2011). Economic decision-making in poverty depletes behavioral control. The BE Journal of Economic Analysis \& Policy, 11(1), 1935-1682. https://doi.org/10.2202/1935-1682.2973

Wagmiller Jr, R. L., Lennon, M. C., Kuang, L., Alberti, P. M., \& Aber, J. L. (2006). The dynamics of economic disadvantage and children's life chances. American Sociological Review, 71(5), 847-866. https://doi.org/10.1177/000312240607100507

Weitoft, G. R., Hjern, A., Batljan, I., \& Vinnerljung, B. (2008). Health and social outcomes among children in low-income families and families receiving social assistance-a Swedish national cohort study. Social Science \& Medicine, 66(1), 14-30. https://doi.org/10.1016/i.socscimed.2007.07.031

Winning, A., Glymour, M. M., McCormick, M. C., Gilsanz, P., \& Kubzansky, L. D. (2016). Childhood psychological distress as a mediator in the relationship between early-life social disadvantage and adult cardiometabolic risk: Evidence from the 1958 British birth cohort. Psychosomatic Medicine, 78(9), 1019-1030. https://doi.org/10.1097/PSY.0000000000000409 